\title{
Stock Plant Production and Management Basics for Small Greenhouse Businesses ${ }^{1}$
}

\section{Dr. James L. Gibson and Christopher B. Cerveny ${ }^{2}$}

Vegetative propagation is an important component of ornamental plant production, because noteworthy characteristics such as flower color or leaf variegation remain true to type from the stock plant, unlike the varied results achieved through seedling propagation. Therefore, maintaining good stock or "mother plants" is critical for success down the road. Poor stock plant management leads to poor quality cuttings. The following information provides some basic guidelines for successful stock plant management and stem cutting production.

\section{Background}

Knowing how the vegetative propagation industry has evolved is just as important as the principles behind stock plant production and management. Breeders are the first to develop a new plant line by conducting massive evaluation trials for selection of premium plant characteristics, some of which include drought tolerance, flower color, and growth habit.

After a plant has been selected for propagation, its numbers are increased through mother plant production. Offshore production of stock plants, mainly in Central America, has been the strategy with which to take advantage of ideal environmental conditions, shipping, and labor costs. Cuttings are harvested from these plants and are shipped to the United States. Propagation firms have established networks of specialized propagators, called rooting stations, which propagate the cuttings and ship to clients either regionally or on the national level.

Because new lines of plants are being developed every year, most of the recently introduced vegetatively propagated species are patented or protected; therefore, the greenhouse facility is not granted the right to propagate these plants for profit. This standard is similar to the rule for downloading free music off the internet: there are royalties involved with producing music and music has copyright protection or patents. The same is the case for newly developed plant material and the penalties can be just as stiff. Today the industry is carefully monitored for plant quality and business integrity because the amount of investment for clean (virusand disease-free) plants is very expensive. Before deciding to grow stock plants, make sure that the species and varieties you want to grow are legal to propagate. Be sure to check all plant labels carefully

1. This document is ENH1021, one of a series of the Environmental Horticulture Department, Florida Cooperative Extension Service, Institute of Food and Agricultural Sciences, University of Florida. Original publication date December 7, 2005. Please visit the EDIS web site at http://edis.ifas.ufl.edu.

2. Dr. James Gibson, Assistant Professor, Chris Cerveny, Graduate Research Assistant, Environmental Horticulture Department, West Florida Research and Education Center, Milton FL 32583

The Institute of Food and Agricultural Sciences (IFAS) is an Equal Opportunity Institution authorized to provide research, educational information and other services only to individuals and institutions that function with non-discrimination with respect to race, creed, color, religion, age, disability, sex, sexual orientation, marital status, national origin, political opinions or affiliations. U.S. Department of Agriculture, Cooperative Extension Service, University of Florida, IFAS, Florida A. \& M. University Cooperative Extension Program, and Boards of County Commissioners Cooperating. Larry Arrington, Dean 
before reproducing plants for profit. If the label has a plant patent number or states PPAF, do not propagate. When in doubt, it is better to refrain than to risk the often extreme fines.

\section{Plant Selection}

Healthy and disease-free plants are crucial to a successful stock plant program. While all stock plants should be healthy and vigorous, pick only the cuttings from the best-looking garden plants. Propagate them in the same way as your other cuttings, but remember to transplant them into larger containers after sufficient roots develop (Fig. 1). This ensures that the plants do not become stunted and stressed before you plant them into the final stock plant container.

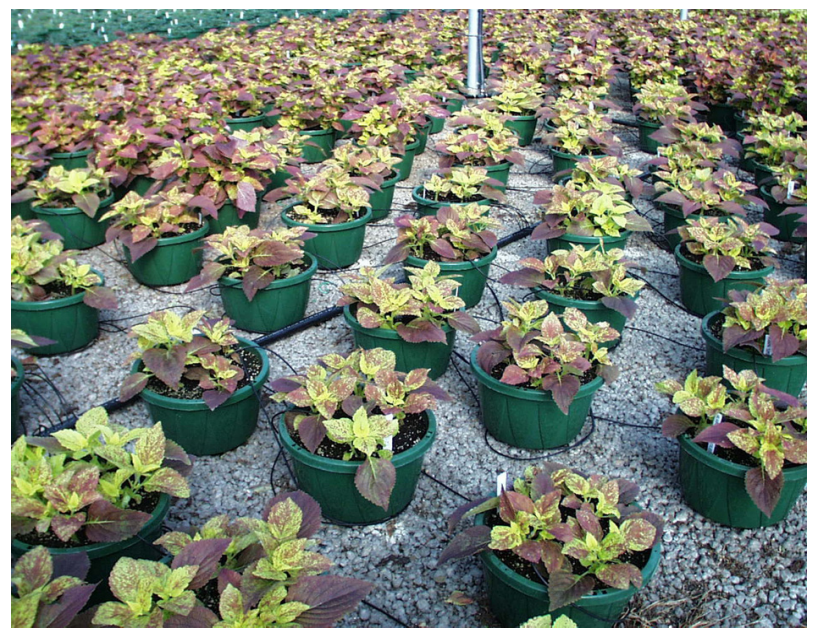

Figure 1. Stock plants of vegetative coleus should be grown in larger containers such as 8- to 10-inch pots because of their high water requirement.

\section{The Growing Environment}

Stock plants are mainly grown on benches or in hanging baskets for ease of harvesting the cuttings. If benches are not available, consider placing stock plants on large inverted pots to avoid the potential spread of water-borne diseases from one container to the next.

\section{Pest Management and Sanitation}

Insects such as whiteflies, thrips, and aphids can be a severe threat to clean stock plants. Conduct routine inspections of the foliage for eggs and immature stages of insects. Before filling greenhouses with stock plants, make sure that pest populations are significantly reduced. This is also the ideal time to remove weeds and plant debris and to sanitize benches, floors, roofs, and sidewalls. Surfaces can be cleaned with a mild detergent and $10 \%$ bleach solution.

For more information on pest identification and removal, visit http://edis.ifas.ufl.edu/ TOPIC_Nursery_Pest_Management.

\section{Irrigation and Water Quality}

An efficient irrigation system is required for cutting production. The best way to avoid water stress is to have an automatic watering system in place. Single, double, or ring-drip emitters are excellent water delivery systems for stock plants. Although it is effective, avoid overhead watering from sprinklers or by hand because it creates the ideal environment for foliar and root diseases. Test the water quality at least once a year to monitor the electrical conductivity or EC (soluble salts), $\mathrm{pH}$, and alkalinity (water hardness). A high salt concentration or $\mathrm{pH}$ due to poor water quality can disrupt water relations and lead to nutrient disorders in the stock plant.

For more information on nutritional monitoring, visit http://edis.ifas.ufl.edu/pdffiles/EP/EP15200.pdf.

\section{Containers}

Popular container sizes for stock plants range from 6.5- to 15-inch pots. Large containers are preferred because they require less frequent watering. However, if you are growing stock plants for a short period of time, smaller containers may be more appropriate.

\section{Potting Media}

Several types of potting media can be used to grow stock plants, as long as some basic requirements are met. Stock plant growers require a potting medium that retains moisture but provides adequate oxygen to support the plant. The traditional components of horticultural media include some combination of the following: perlite, vermiculite, peat moss, foam pellets, coconut husk, pine bark, or 
sand. One would typically not incorporate all of the mentioned components because of the expense. There are many acceptable premixed formulas available for purchase. One important thing to remember is to choose a mix that will not break down quickly, because stock plants will be grown for several months.

\section{Planting}

Stock plants are typically established for 6 to 12 weeks to encourage branching and canopy development. Producers normally plant two to three cuttings per 6.5- to 15 -inch container. For better establishment, allow some space between cuttings so that light can penetrate into the interior of the plant.

\section{Spacing}

The general rule of thumb for spacing stock plants is to keep just enough space to provide proper air movement between plants, but not any more than they need, keeping in mind that you will be trimming these plants back as you harvest the cuttings.

\section{Temperature}

In general, stock plants should be grown with 70 to $75^{\circ} \mathrm{F}$ day and 65 to $68^{\circ} \mathrm{F}$ night temperatures. The number of cuttings obtained and the quality (size and vigor) are affected by temperature. Warmer temperatures speed up the development of cuttings, but excessive temperatures can delay growth. Stock plants should be kept under shade during warmer periods of the year to avoid excessive stress on the plants. You can spray a shading compound on the glass or use shade cloth. Shade cloth is available in varying degrees of shade. Some examples include $30 \%, 50 \%$, and $70 \%$ shade, which allow $70 \%, 50 \%$, and $30 \%$ light penetration, respectively.

\section{Light}

Light is essential for creating chemical energy (sugars) in plants. These sugars or carbohydrates in cuttings contribute to root and shoot growth during propagation. The three components of light (duration, quantity and quality) should be considered when growing stock plants. Duration of light, or photoperiod, is important to stock plant production because of its effects on flowering of photoperiodic plant species. Flowering is not desired on cutting material and can be an inhibitor of leaf development and rooting. One way to make up for shorter day lengths is to apply "night lighting" to extend the photoperiod. Most growers string a short series of incandescent light bulbs through the growing area and set them with timers. The night interruption lighting should be applied for approximately four hours from 10:00 pm to 2:00 am. Light quality affects shoot elongation of stock plants and the performance of cuttings after they are taken from the mother plant. The light intensity or quantity should be enough to provide adequate light to the new shoots without introducing stress to the foliage.

\section{Pinching and Trimming}

Soft or hard pinches are conducted before harvesting to keep stock plants in a non-flowering state and to increase the number of lateral branches. These branches combine to form a dense "scaffold" of plant material so that cuttings are easily harvested. Trimming is a routine activity to improve airflow between plants and to control unnecessary vegetation. However, excessive trimming should be avoided as this interrupts the fine balance of root to shoot growth and can subsequently affect cutting quality.

\section{Fertilization and Nutritional Monitoring}

Nutritionally stressed stock plants produce nutritionally stressed cuttings. Stock plants that are fertilized appropriately will produce cuttings with enough nutrient reserves to "carry" them through the rooting stage of propagation. Soluble fertilizers offer a steady rate of nutrients to the stock plant. Slow-release fertilizer is not recommended for stock plants because nutrients can be released rapidly during warm periods. Stock plants fertilized with high rates of nitrogen will produce soft, lush cuttings that are not desirable and may have difficulty rooting. A general nitrogen concentration range for stock plants is 150 to $250 \mathrm{ppm}$ (parts per million). 


\section{Stock Plant Age}

Stock plant producers should produce herbaceous cuttings that have actively growing shoots (meristems). Tissues that are either too young or too old will root more slowly than cuttings taken at the proper stage of maturity. Cuttings that are too old do not branch as extensively as younger, softer tissue. Fully developed flowers on cuttings are a sure sign that tissue may be too old to root optimally (Fig. 2). A proper pinching and trimming program will eliminate most problems associated with cutting age.

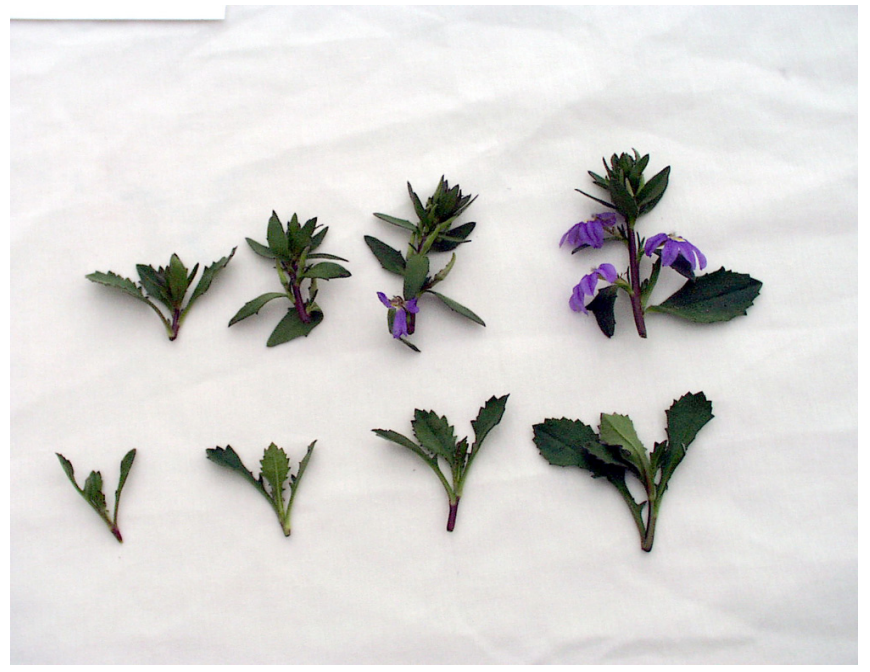

Figure 2. Scaevola cuttings on the top row are less desirable because of the flowering structures that reduce cutting vigor in propagation.

\section{Harvesting}

Healthy stock plants can tolerate frequent harvests. There are two types of harvest strategies, selective harvesting and hedging (grazing). If you desire only the largest, highest quality cuttings, then a selective harvest should be conducted. In hedging, all cuttings on the stock plant that fit the minimum quality standards of the propagator are harvested. Hedging is usually reserved for high demand times, or for very large scale producers.

Early morning is the best time to harvest, because plants are more turgid then (their cells retain more water) than they are later in the day. Make sure that stock plants are fully hydrated before harvesting to ensure that cuttings can withstand the stress of severance from the mother plant. Each cutting should be between 1.5 to 3.5 inches in length and have at least 3 to 5 leaves on it (Fig. 3). A "leggy" cutting that has a thin stem and/or a reduced leaf area will not root optimally. Avoid stock plant contamination by making cleanliness a priority. Use mild bleach and dish detergent solution ( 2 fl. oz. bleach +1 tbsp. detergent per 5 gal. water) to wash hands and tools before and after harvesting cuttings.

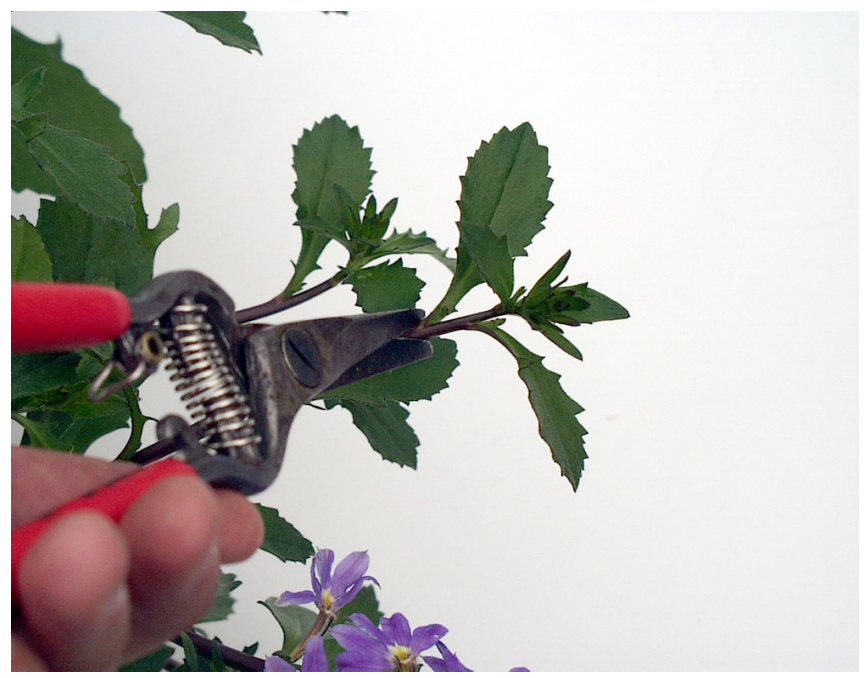

Figure 3. Cuttings should be harvested with 3 to 5 leaves on them.

\section{Cutting Tools}

Scissors, clippers, knives, and razor blades are several types of cutting tools used to remove cuttings from stock plants. Sharp cutting tools are essential because they tend to avoid the risk of destroying the cutting base. Dull tools can crush the basal tissue and prevent or delay rooting. Cutting tools should be dipped in a $10 \%$ sodium hypochlorite solution repeatedly during harvesting (Fig. 4).

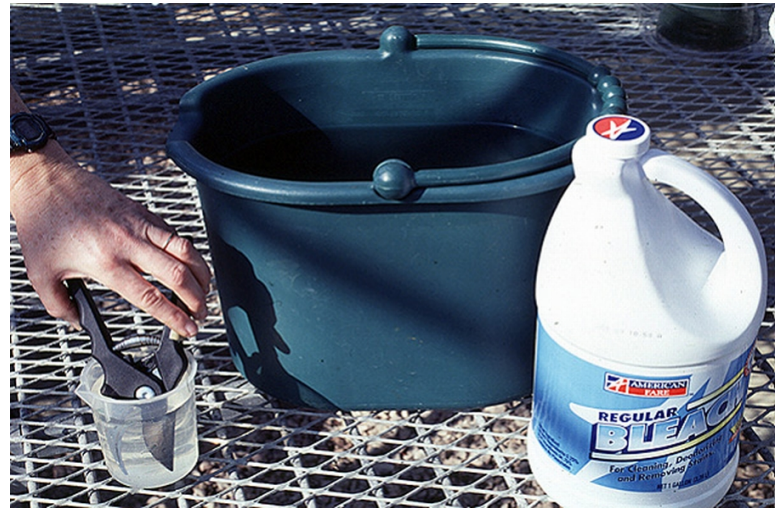

Figure 4. A 10\% sodium hypochlorite solution can be used to disinfect cutting tools. 


\section{Conclusion}

Producing and managing stock plants is a time-consuming responsibility that requires your constant care and attention. The ultimate goal is to produce high-quality plants legally and inexpensively to sell in your business. Use the information above as general guidelines for stock plant production and management.

\section{Resources}

Related EDIS extension publications:

- Propagation of Landscape Plants: http://edis.at.ufl.edu/pdffiles/MG/MG10800.pdf

- Propagation of Woody Ornamentals by Cuttings: http://edis.at.ufl.edu/EP030

Other grower websites etc.

- Anon. Ensuring Oglevee quality: Purchasing clean stock. Oglevee.

http://oglevee.com/cvi_variety.htm (May 2002).

- Gibson, J. and L. Greer. Retail reflections:

Profiting by propagating? North Carolina State

University Commercial Floriculture. http://www.ces.ncsu.edu/depts/hort/floriculture/ RR/Propagation/prop_veg_annuals.htm (May 2002)

- Michigan State University Extension. Geranium stock plant production. Michigan State University Horticulture.

http://www.msue.msu.edu/msue/imp/mod21/ 21000167.html (May 2002).

- Pasian, C. Poinsettia stock plants. The Ohio State University Horticulture. http://floriculture.osu.edu/archive/may99/postock.html (May 2002).

- Paul Ecke Ranch. Poinsettia stock plant production. Paul Ecke Ranch. http://www.ecke.com/html/tibs/tib_fastcrop.html (May 2002).

- University of New Hampshire Cooperative Extension. Cost of producing cuttings. University of New Hampshire Horticulture.
http://ceinfo.unh.edu/Agriculture/Documents/ floraBGT.htm (May 2002).

- Wulster, G. Poinsettia Stock Plant

Management: Fundamentals pay off. Rutgers

Horticulture.

http://aesop.rutgers.edu/ Floriculture/

publications/POINTSTK.HTM (May 2002). 